\title{
Sínodo da Amazônia: novos caminhos para a igreja e para uma ecologia integral
}

\author{
The Amazon Synod: new paths for the
}

church and for integral ecology

NADI MARIA DE ALMEIDAa

AGENOR BRIGHENTI

\section{Resumo}

Seguindo a metodologia do processo de preparação do Sínodo da Amazônia, que dedicou um longo tempo à escuta dos povos da Região, em um primeiro momento, este artigo dá voz a três grandes clamores que vêm da Amazônia e de sua brava gente: o grito que vem das águas, o grito que vem da flora e da fauna e o grito dos povos da Amazônia. Em seguida, tendo presente o modo como o Evangelho chegou naquelas terras e a heroica resistência, sobretudo de indígenas, negros e mestiços, na defesa secular de suas culturas e religiões, se acena para um modelo de evangelização em clave decolonial, tanto em relação à ecologia como aos povos da Região.

Palavras-chave: Sínodo. Amazônia. Evangelização. Decolonização. Conversão.

\section{Abstract}

Following the methodology of the process of preparing the Amazon Synod, which devoted a long time to listening to the peoples of the Region, at first, this article gives voice to three great

\footnotetext{
a Pontifícia Universidade Católica do Paraná (PUCPR), Curitiba. Mestre em Teologia, e-mail: nadinadimaria@gmail.com

b Pontifícia Universidade Católica do Paraná (PUCPR), Curitiba. Doutor em Teologia e-mail: agenor.brighenti@pucpr.br
} 
cries that come from the Amazon and its brave people: the cry that comes from the waters, the cry that comes from flora and fauna and the cry of the peoples of the Amazon. Then, bearing in mind the way the Gospel arrived in those lands and the heroic resistance, especially of Indians, blacks and mestizos in the secular defense of their cultures and religions, beckon to a model of evangelization in decolonial clef, both in relation to ecology as to the peoples of the Region.

Keywords: Synod. Amazon. Evangelization Decolonization. Conversion.

O Sínodo da Amazônia é muito mais que um evento regional. Segundo o Instrumentum Laboris, Amazônia é "um novo sujeito", a ser considerado no contexto nacional e mundial, tanto pela Igreja como pela sociedade como um todo. Um sujeito, frisa o documento, "não considerado suficientemente", mas que se impõe como "um interlocutor privilegiado" (Instrumentum Laboris 2).

É um novo sujeito, pois, desde a Amazônia — de suas práticas, necessidades e clamores - surgem luzes capazes de abrir "novos caminhos para a Igreja”, não só na região como também em âmbito universal. Questões como inculturação da liturgia, uma organização da Igreja desde o exercício da sinodalidade, novo modelo de presbiterato, a efetiva participação das mulheres nos ministérios e nos espaços de discernimento e tomada de decisão, não são desafios restritos à região amazônica. O mesmo se pode dizer em relação à ecologia, em uma região em que, por um lado, sobretudo os povos originários convivem com a natureza no respeito ao equilíbrio dos ecossistemas e, por outro, não poucas agressões ao meio ambiente são espelho de práticas predadoras e devastadoras de uma economia de rapinagem em escala mundial. Não somente se precisa do equilíbrio ambiental da Amazônia para assegurar a vida humana e seus ecossistemas no planeta, como se pode aprender dos povos originários modos de viver capazes de restabelecer uma relação sadia entre natureza e ser humano. No âmbito religioso e eclesial não é diferente. Não somente a Igreja em âmbito universal precisa assegurar às comunidades eclesiais da região os meios necessários para viver digna e integralmente a fé cristã, como pode aprender das posturas decolonizadoras dos povos da floresta como evangelizar sem colonizar, no respeito às culturas e às religiões nativas, tecidas de sabedoria humana e dinamismo do Espírito.

De maneira muito oportuna, o Sínodo da Amazônia, através de um amplo processo de escuta dos povos da região e do discernimento de seu contexto sócio-cultural, se propôs ousar a abrir "novos caminhos para a Igreja" e a 
conclamar a sociedade como um todo, incluídos os cristãos, a implementar uma ecologia integral. É o que colocaremos em relevo neste texto. Seguindo a metodologia do processo de preparação do Sínodo, que dedicou um longo tempo à escuta, em um primeiro momento, daremos voz a três grandes clamores que vêm da Amazônia e de sua brava gente. Em seguida, tendo presente o modo como o Evangelho chegou naquelas terras e a heroica resistência, sobretudo de indígenas, negros e mestiços na defesa secular de suas culturas e religiões, vamos acenar para um modelo de evangelização em clave decolonial.

\section{Um Sínodo à escuta dos clamores da Amazônia}

Ainda que sufocados ou silenciados, da Amazônia e seus povos emerge o clamor pelo cuidado da "casa comum", que a Igreja reunida em Sínodo se propõe a ouvir e responder por uma ação profética e transformadora. A Amazônia é una e múltipla. Provoca indignação ética a Amazônia desmatada pelo fogo e pelo inescrupuloso agronegócio, denunciados por muitos e impetrados por tantos outros. Há também a Amazônia das populações tradicionais, que vivem dos recursos da natureza, com técnicas que não afetam o meio ambiente. Mas, há ainda outra Amazônia, pouco conhecida e bem conservada, quase intocada. É a Amazônia dos povos da floresta, seringueiros, indígenas, quilombolas, castanheiros, ribeirinhos...

Da Amazônia una e múltipla brotam clamores, respeitosamente escutados pelo Sínodo dos Bispos. Escutemos pelo menos três: o clamor que vem das águas, o clamor que vem da fauna e da flora e o clamor que vem dos povos da floresta.

\subsection{O clamor que vem das águas}

Ao desembarcar na Amazônia, um primeiro impacto vem da magnitude das águas. Não há como não se impressionar com a imensidão de seus rios, com a chuva tropical e o vapor, palpável até nos poros, que buscam livrar-se de toda indumentária. Os rios são muito mais que rios. Como em toda parte, infelizmente, também nas grandes cidades da Amazônia são também lixeiro. Mas, via-de-regra, são hidrovias, as únicas vias de acesso terrestre a muitas regiões. A queda do nível das águas é ameaça de corte da comunicação e do aprovisionamento de regiões inteiras. Há viagens de barco de mais de uma semana, dias e dias, noites e noites, 
deslizando pelo leito sereno de rios ainda em formação. Para os viajantes, é o tempo com outra medida, da contemplação e da gratuidade esticados numa rede, da conversa franca com companheiros nunca vistos, diferente do time is money e do tempo frenético da cidade. Mas, é tempo também de apreensão. Barcos malconservados e superlotados, não raro são engolidos pela correnteza, interrompendo não só a tranquilidade como quase sempre acabando em tragédias.

Entretanto, a Amazônia não é um mundo à parte. Ela é um mundo, mas dentro do mundo. Nem é só brasileira, pois a pan-amazônia abarca nove países, e nem só dos amazônidas — os povos que a habitam. Na realidade, não é possível pensar o planeta sem a Amazônia. Ela joga na atmosfera, diariamente, 20 bilhões de toneladas de vapor. Do total das águas que alimentam os oceanos, $26 \%$ vêm da Amazônia. Sua importância é ainda mais real, quando se toma consciência que do total da água do planeta, só 3\% é potável e, desta, só 0,7\% é de uso humano. Destes $0,7 \%, 70 \%$ vai para a indústria e só $10 \%$ vai para o consumo humano. 0 contraste, neste uso, sinaliza a exploração que arrisca fazer da Amazônia uma mercadoria, descuidando a prioridade das vidas humanas. O acesso aos recursos hídricos o indicam: no mundo, há mais de um bilhão de pessoas com falta de água; podemos suportar a fome por 17 dias, mas a sede, por apenas 3 dias (cf. BOFF, 2000).

Os rios da Amazônia são cheios de vida. Aninham espécies incontáveis de flora e fauna. O equilíbrio desta biodiversidade, entretanto, já foi quebrado com espécies extintas ou em extinção, que vão dos peixes às tartarugas, consequência da proliferação da pesca predatória. Na época das cheias, os rios estendem seus braços, para além de seus leitos, invadem florestas e cidades, através dos igarapés, levando vida em abundância e não só para os amazônidas. Mas, também pode sobrar água, o nível do rio pode subir de modo anormal e desestabilizar. Ao invadir casas precárias, provoca perdas materiais, expõe flagelados a enfermidades, compromete o aprovisionamento. Fenômeno novo são as construções de grandes barragens, inundando imensidões e provocando desequilíbrio ambiental. A contaminação das águas por empresas mineradoras escasseia o pão na mesa de muitos ribeirinhos.

Dos rios da Amazônia, herdamos muita coisa. De suas águas cálidas, sob temperaturas tão altas que impõem espaços de inatividade, os indígenas nos legaram a delícia do saudável banho diário, visto em antigas culturas de além-mar 
como um atentado à saúde. Nascidos nas Cordilheiras dos Andes, os rios vêm arrastando terra, formando ou engolindo ilhas. Em seu leito, vêm boiando paus e plantas e estampando as águas de tons múltiplos, muito mais visíveis quando dois deles se encontram, como nas proximidades de Manaus. São águas que abrigam de piranhas a jacarés, de grandes e pequenos peixes às centenárias tartarugas, dos botos aquáticos aos "botos terrestres”, sedutores das imprudentes sinhás em cio.

Espetáculo à parte são as chuvas torrenciais, especialmente quando se está no meio do rio, rodeado de água por todos os lados. Pingos grossos, aos milhões, durante horas gotejando sobre a imensidão das águas, brindam a mais bucólica sinfonia. Pensar que isso acontece há milhares de anos, mas que essa sinfonia pode silenciar pela ação inconsequente dos humanos, que foram encarregados precisamente de cuidá-la. Agressores, via-de-regra, vindos de fora, com um olhar sobre a Amazônia não de admiração, respeito e cuidado, mas de cobiça, exploração, lucro e posse. A natureza é uma "coisa" a explorar (Descartes) ou uma "mulher da vida" de que se servir (F. Bacon). É o lado perverso de um projeto civilizacional, em muitos espaços, reduzido a depredar a natureza e a coisificar o ser humano. A Igreja na Amazônia e para além dela precisa e quer cuidar das águas para proteger e promover a vida.

\subsection{O clamor que vem da flora e da fauna}

De um solo pobre e relativamente recente, irrompe uma floresta densa e exuberante. Como frisa Leonardo Boff, é mais um dos milagres da Amazônia, pois suas florestas se alimentam muito mais da chuva e das folhas cadentes das árvores do que do solo que a ampara; muito mais de cima do que de baixo. Por isso, cortar a floresta é dar início a um processo quase irreversível de desertificação. Dificilmente o solo teria capacidade de produzir outra floresta, só gestada graças a um frágil equilíbrio entre vários elementos em cadeia (cf. BOFF, 1995).

O que seria dos amazônidas sem a floresta amazônica, sem sua fauna e sua flora? Eles dependem dos rios e, estes, das chuvas e, estas, das florestas. É impossível pensar o amazônida sem as florestas que vestem o seu chão. Estas lhe dão do alimento ao medicamento, da poesia aos mitos que tocam seus mistérios. Mas, às vezes, temos a sensação de que perdemos a batalha por sua preservação. Grandes interesses em jogo corrompem inclusive as autoridades que estão ali para 
guardá-la. A cobiça e a ganância dos madeireiros tombam e queimam. A agroindústria agradece, cerca ou lavra o chão, põe pasto ou envenena o solo. Seringueiros, ribeirinhos e indígenas passam, então, como nunca antes visto, a conhecer a violência e o êxodo e, com ele, as periferias das cidades, a desocupação e a fome, apesar de toda a resistência, que já fez muitos mártires e tantos outros marcados para morrer, como Dom Erwin Krautler.

A invasão da Amazônia começou ainda no final do século XIX, com a chegada de levas e levas de migrantes nordestinos, trazidos para atender a alta demanda mundial de borracha (BARBOSA DE ALMEIDA, 2009, p. 18). Eles eram recrutados em Belém, atraídos pela alta produtividade das seringueiras dos altos rios Purus e Juruá. Os recém-chegados massacravam os habitantes da região indígenas da língua Pano e seringueiros vindos do Peru. O pico da exploração do látex deu-se em 1912, quando a produção atingia 42 mil toneladas, representando $42 \%$ das exportações nacionais, incluindo o café. Mas, naquele mesmo ano, os ingleses começaram a exportar sua produção, obtida na colônia da Malásia, desbancando, em pouco tempo, o látex brasileiro. Um atrás de outro, os seringais dos rios Juruá, Purus, Madeira, Tocantins e Negro faliram (ALLEGRETTI, 2009, p. 23).

Mas a invasão mais grave deu-se nos anos 70, sob a ditadura militar, com o slogan “Terra sem homens para homens sem terra”. Empresários e colonos, vindos do sul do país, passaram a ocupar terras, principalmente no Acre, com documentos falsos, expulsando a ferro e fogo os antigos seringueiros (SCHMINK, 2009, p. 26). Houve resistência, sobretudo na bacia do Rio Purus, nos municípios de Xapuri e Brasiléia, sudoeste do Estado. Seringueiros como Wilson Pinheiro, Chico Ginú e Chico Mendes começaram a chamar a atenção das autoridades para a truculência de que os trabalhadores da floresta vinham sendo vítimas. O primeiro sindicato de trabalhadores rurais da região foi fundado em 1979 (BARBOSA DE ALMEIDA, 2009, p. 19). A cada avanço dos seringueiros em seus direitos, os falsos donos das terras reagiam. Passo significativo só seria dado em dezembro de 1988, com a comoção causada pelo assassinato do líder de Xapuri, Chico Mendes. Em julho daquele ano, o Conselho Nacional dos Seringueiros já tinha elaborado um "Plano de Desenvolvimento Comunitário Reserva Extrativista da Bacia do Rio Tejo" (ALLEGRETTI, 2009, p. 25). Era uma iniciativa inédita, pois a ideia era fundar uma cooperativa de trabalhadores para gerenciar a produção, levando em conta os cuidados ambientais para não exaurir a floresta. O BNDES aprovou o projeto. A 
reação dos fazendeiros foi violenta, por meio de atentados, boicotes e ações judiciais. A solução viria em 1990, quando um decreto federal determinou a criação da primeira reserva extrativista do Brasil, com cinco mil quilômetros quadrados (BERNO DE ALMEIDA, 2009, p. 29). Após cem anos de batalha, a guerra da ocupação do Alto Juruá estava vencida, um passo importante para salvação dos seringueiros e da floresta (BARBOSA DE ALMEIDA, 2009, p. 20).

Segundo dados oficiais, até o momento, 17\% da Amazônia já foi desmatada. O número impressiona, mas, se o projeto militar tivesse prevalecido, hoje a devastação teria atingido 40\% da região. Ao contrário, hoje, 40\% da Amazônia está legalmente protegida, sendo $15 \%$ por reservas ambientais e $25 \%$ por terras indígenas. Grande parte deste avanço se deve à aplicação do modelo de Reservas Extrativistas, iniciado por Chico Mendes (SCHMINK, 2009, p. 26). Nessas unidades de conservação, implementadas em terras públicas, cabe às populações tradicionais a gestão dos recursos naturais (BARBOSA DE ALMEIDA, 2009, p. 21). 0 objetivo básico é proteger a biodiversidade e a cultura das populações, cuja subsistência se baseia no extrativismo e, complementarmente, na agricultura de subsistência e na criação de animais de pequeno porte. A concessão é gratuita e está condicionada à produção, sem danos à ecologia. Isso é apenas reconhecer e acolher o que as populações locais já estavam habituadas a fazer (SCHMINK, 2009, p. 26). Num momento em que o mundo desperta para os dramáticos efeitos das mudanças climáticas, as unidades de conservação de uso sustentável surgem como uma alternativa para o dilema que opõe desenvolvimento e meio ambiente (ALLEGRETTI, 2009, p. 23).

Sempre que ouvimos o grito que ecoa do meio da floresta, de tantas e tantos defensores indefesos, reacende a esperança, mas à condição que esse grito nos remova as entranhas e nos faça parceiros de uma causa que é de todos. Os amazônidas não terão futuro se os deixarmos sozinhos. E, se eles sucumbirem, todos estaremos ameaçados. A Igreja no Brasil precisa ser a samaritana da Amazônia, como têm sido o incansável o Conselho Indigenista Missionário (CIMI) e tantas outras organizações, que desempenham uma imprescindível missão profética, na defesa de indefesos, numa região permeada de ataques à biodiversidade, da qual dependemos todos. O Sínodo da Amazônia, com o Papa Francisco, vem recordar que "tudo está interligado": a natureza, a fauna e a flora, e os seres humanos. E estes com Deus. A fé cristã é inter-relação dos seres humanos entre si, com a natureza, e sua fonte originária que é o Criador. 


\subsection{O clamor que vem dos povos da Amazônia}

A maior riqueza da Amazônia, entretanto, não são suas robustas e exuberantes florestas, nem seus caudalosos e jovens rios ainda em formação, muito menos seu solo ou rico subsolo, que guardam tesouros capazes de suscitar a cobiça inescrupulosa do grande capital ou da indústria farmacêutica internacional. A maior riqueza da Amazônia são os amazônidas, os povos que habitam aquele chão. Aliás, a verdadeira porta de entrada na ecologia é o ser humano, por mais que ele faça parte da complexidade de uma biodiversidade, no seio da qual cada espécie não é uma, mas peça de uma engrenagem que conforma a cadeia da vida. Ainda que se tenha de romper com o antropocentrismo do projeto civilizacional moderno, que fez do ser humano antes um "explorador" do que um "guardião" da Criação, nenhuma outra criatura, por mais importante, exótica ou rara que seja, se iguala à sua grandeza. Isso não é motivo de orgulho ou de dominação sobre as demais criaturas, mas de responsabilidade maior em cuidar da casa (oikos) de todos. O ser humano não está na Terra, é terra. Sua vida, projeto de plenitude, está vinculada ao conjunto da obra da Criação; é parte integrante de uma rica biodiversidade em cadeia. Quando uma espécie desaparece, não é apenas menos uma, mas significa a ruptura do equilíbrio de uma cadeia harmônica.

A grandeza do ser humano está no fato de ser não apenas criatura. Ele é criatura co-criadora, criado à imagem e semelhança de Deus. Como afirma São João da Cruz, para o Criador, um só pensamento em Deus, ainda que por um só de seus filhos, vale mais que toda a obra da Criação. É a grandeza incomensurável do amor, que tem sua fonte num Deus que é Amor. Mas, bem sabemos que a liberdade do ser humano é o sofrimento de Deus, pois é também a possibilidade real de destruir sua obra, ou seja, de rejeitar seu amor, de recusar o fruto de seu amor, de perder-se (cf. BOFF, 2001).

Não podemos perder de vista que a Amazônia, antes de tudo, abriga amazônidas que tecem sonhos e utopias, culturas e religiões, línguas e valores, verdadeiras civilizações. Tão somente a Amazônia brasileira abriga 24 milhões de habitantes. De cada dez brasileiros, um vive na Amazônia (BERNO DE ALMEIDA, 2009, p. 28). Eles são ribeirinhos, quilombolas, indígenas, piaçabeiros, pescadores artesanais, seringueiros, castanheiros, carvoeiros, artesãos (do arumã, do tucum, do cipó-ambé), moradores das cidades, quebradeiras de coco babaçu, peconheiros 
(coletores de açaí). Apesar do desastre do encontro com os brancos, a região guarda ainda mais de uma centena línguas, faladas por povos de tradições milenares (BARBOSA DE ALMEIDA, 2009, p. 18-21). Segundo o Atlas das línguas no mundo em risco de desaparecimento, da Unesco, no Brasil, existem 150 línguas indígenas em uso. O idioma falado por maior número de indígenas é o xavante. No entanto, em vários povos indígenas, o idioma original é dominado por menos de quinze pessoas. O Yawalapiti, por exemplo, é conhecido por apenas 10 dos 222 indígenas que vivem no Alto Xingu. O Apiaká é falado por um único índio entre os 192 que permanecem no Mato Grosso. Já são 13 as línguas totalmente extintas, como o Krengê, que até 1983, era falado por um único índio no Alto Guamá, no Pará (BERNO DE ALMEIDA, 2009, p. 29). As tradições orais, o saber xamânico e os conhecimentos ecológicos e cosmológicos, pouco a pouco, deixam de ser transmitidos para as gerações mais novas. E o português, que se aprende na televisão, na escola e nos locais de trabalho, já domina as conversas (ALLEGRETTI, 2009, p. 25).

Com paciência e sabedoria, os amazônidas aprenderam a conviver harmoniosamente com a Amazônia, escandalosamente generosa com seus filhos. O cuidado destes chega ao extremo de pedir licença a uma árvore para colher seu fruto. Ela Ihes dá o alimento e os medicamentos, a capacidade de maravilhar-se e a inspiração, as alegrias e a sombra de seu descanso. Seus mistérios são sondados em seus mitos e o mundo-do-além, venerado em seus ritos. Os espaços são imensuráveis, a perder de vista no horizonte, mas não para gananciosos arrozeiros, madeireiros, fazendeiros e mineradores, sempre terra pouca que justifica o gradativo avanço da cerca, a ferro e fogo. Para estes, os amazônidas não são a riqueza da Amazônia; ao contrário, são a barreira do progresso, de um denominado “desenvolvimento sustentável", mas que não é outra coisa que sustentar o atual processo predatório de progresso, destruidor do paraíso verde dos amazônidas.

Em poucas décadas de invasão, quantos povos já desapareceram, quantos idiomas silenciaram, quantos valores se perderam, enfim, quanta sabedoria reduzida a cinza. Quantas religiões, seculares lugares de encontro com Deus, fruto da graça e da busca sincera de espaços de eternidade na precariedade do presente, foram jogadas no lixo da história. Se para o Criador um único pensamento em Deus, mesmo que de um só de seus filhos, vale mais que toda a obra da Criação, como calcular a perda do desaparecimento de povos inteiros, de 
mitos tecidos durante séculos, de valores discernidos na lida do cotidiano, no seio de culturas e religiões. Inescrupulosamente, empresas multinacionais patenteiam a sabedoria que restou e uma cultura de dominação invade os lares pelos meios de comunicação e por um sistema mercantilista.

Os amazônidas não estão fechados às conquistas da humanidade em outros rincões do planeta e têm consciência que isso pode lhes favorecer. O que eles querem é serem eles mesmos, em seu espaço vital, com o qual conseguiram estabelecer uma relação estável e harmônica. Não são contra o novo, mas contra o que destrói. Não se opõem ao diferente, mas aos que são incapazes de uma relação de alteridade. Em resumo, eles não se conformam em ter de viver na miséria numa terra de fartura, sendo expulsos de suas terras, para viverem confinados nas periferias já de grandes cidades. Eles, simplesmente, reivindicam o direito de sonhar com um paraíso, em grande medida já presente em meio ao verde das florestas e o murmúrio dos rios. Com o Sínodo da Amazônia, a Igreja busca ter o rosto dos amazônidas, ser sacramento do Reino de Deus do jeito de suas culturas e religiões. Cristianismo, ao chegar, não faz tábula-rasa, se enxerta, se encarna, potencializa a realidade assumida com o dinamismo do Evangelho, pois não propõe à humanidade nada mais do que sermos plenamente humanos, no âmago da "casa comum", dádiva do Criador às suas criaturas cocriadoras (cf. BOFF, 1996).

\section{Um sínodo para abrir novos caminhos para a Igreja}

A Amazônia é importante para a preservação da vida no planeta, razão pela qual, segundo o Secretário Geral do Sínodo dos Bispos, Cardeal L. Baldisseri (2018), "ela entrou para o coração da Igreja" e é, hoje, uma "prioridade da Igreja e do papa Francisco"1 (Cf. BALDISSERI, 2018). Contudo, para muitos, a Amazônia é apenas fonte de riqueza "inesgotável"; olham para ela com ganância predatória, querendo apenas explorar, usufruir, não se importando com o que ameaça a vida e os povos da Região. No entanto, como adverte Viola (2002), não se pode explorar as riquezas da Amazônia quando não se é capaz de proteger a vida humana e seus ecossistemas. Sabemos que a atmosfera tem capacidade limitada de absorver

\footnotetext{
${ }^{1}$ Cf. Lorenzo Baldisseri, "Comenta o Documento Preparatório sobre a assembleia sinodal de 2019", apresentado em: 08 Junho, 2018 na Sala de Imprensa da Santa Sé - a Amazônia no coração da Igreja, acesso em 01 Fevereiro, 2019, https://www.youtube.com/watch?v=3pOQHKG0eOY.
} 
toda a poluição provocada pela ganância humana, razão pela qual é preciso fazer uso dela com precaução.

\subsection{Novos caminhos para a Igreja em relação à ecologia}

O Papa Francisco, em sua Carta Encíclica Laudato Si’ (LS), lança um convite urgente para "renovar o diálogo sobre a maneira como estamos construindo o futuro do planeta":

Precisamos de um debate que nos una a todos, porque o desafio ambiental que vivemos, e as suas raízes humanas, dizem respeito e têm impacto sobre todos nós. [...] As atitudes que dificultam os caminhos de solução, mesmo entre os crentes, vão da negação do problema à indiferença, à resignação acomodada ou à confiança cega nas soluções técnicas. Precisamos de nova solidariedade universal (LS 14).

Igualmente, o Papa afirma que a consciência ecológica "exige reconhecer os próprios erros, pecados, vícios ou negligências e arrepender-se de coração, mudar a partir de dentro" (LS 218). Sabemos que são os povos da Região os que mais sofrem com a situação devastadora da Amazônia. Por isso, têm sido eles próprios quem primeiro têm levantado a voz, gritando por socorro. Quantos e quantas pessoas militantes da causa já tombaram na luta ou continuam resistindo. A lgreja, presente na Região e fora dela, angustiada diante dessa situação, já há anos decidiu não ficar mais calada e indiferente. Tem procurado assumir com coragem sua missão profética ${ }^{2}$. Nesta perspectiva, o Documento Preparatório do Sínodo Pan-Amazônico (Lineamenta) afirma a necessidade de "dedicação, preservação e restauração do bioma e com seus habitantes". Trata-se de um sínodo regional, mas com "horizonte planetário", pois a Amazônia, considerada pulmão do mundo, é importante para todo o planeta. Com este Sínodo, decididamente, a Igreja assume o compromisso de unir-se ao grito dos povos originários e habitantes da região, procurando ser uma presença profética na defesa da vida e da casa comum.

Com o Sínodo para a Amazônia, a Igreja se propõe a abrir e a trilhar novos caminhos. Um caminho que tem como método a sinodalidade, porque a missão deve ser nova, relevante, encarnada na realidade, com e a partir do protagonismo do próprio povo de Deus, no seio da sociedade. Para isso, precisa-se de uma

\footnotetext{
2 "O Senhor ouviu o clamor do seu povo" (cf. Ex 2,24; 7,34)
} 
mentalidade nova, um novo olhar, uma consciência multidimensional, intercultural e plural do ser cristão. Impõe-se a necessidade de ver e de conhecer a realidade dos povos originários e dos amazônidas em geral, a fim de posicionar-se na realidade local de um jeito novo e próprio, com o protagonismo dos povos da Região. É preciso acolher as angústias e esperanças dos povos da Amazônia, aproximando-se, vendo de perto e ouvindo, tocando e sentindo a realidade da Amazônia, dos seus povos, em sua pluralidade de culturas³.

Por experiência, no Sínodo, a Igreja reconhece que, ao longo da história, decisões tomadas de cima para baixo, sem o conhecimento da realidade e sem escutar os povos locais, mesmo que com boas intenções, não funcionaram; ao contrário, causaram dor e perdas para a cultura (língua, costumes e tradições). Frisa que, com a renovação do Vaticano II, a Igreja começou um processo de conversão, trilhando novos caminhos em sua ação missionária, a fim de não repetir os erros do passado. Agora, abrem-se "novos caminhos" e se tomam novas atitudes, em vista de uma ação missionária encarnada na realidade e vida dos povos locais. Trata-se de uma atitude corajosa, firme e ousada, verdadeiramente profética e missionária. Segundo Paulo Suess (2019),

o Papa não vai substituir a voz dos povos e episcopados da Amazônia. Ele espera propostas corajosas dos atores da região [...] e do episcopado e povos de outros continentes e regiões se espera que não insistam em conceitos de universalidade, uniforme. [...] com uma compreensão estreita, face às possibilidades de expressar os conteúdos essenciais da fé em vasos culturais diferentes (SUESS, 2019, p. 21).

A. Spadaro (2013, p. 24) ressaltando a expressão da fé na diversidade cultural considera que, fundamentalmente, é preciso "caminhar unidos nas diferenças", pois é “caminho para a unidade", "caminho de Jesus", caminho de conversão que leva à descentralização das estruturas da Igreja, para torná-las mais acolhedoras, dinâmicas e missionárias.

O sínodo é um convite para uma tomada de consciência da realidade que estamos vivendo, assim como para avaliar atitudes que têm atentado à vida, bem como para projetar novos caminhos para a Igreja e para uma ecologia integral. Para isso, o primeiro passo é reconhecer humildemente que historicamente se errou e ter a coragem de pedir perdão, sobretudo, tomando nova direção e buscando novos caminhos, a fim de reverter a atual situação de morte. É preciso

\footnotetext{
${ }^{3}$ Papa Francisco diz que "precisamos nos exercitar na arte de escutar, que é mais que ouvir" (EG 71). 
estabilizar, reparar e restituir a vida, isso porque não basta "sustentar o desenvolvimento" atual, antes se faz necessário reparar e restaurar.

Destarte, o Papa Francisco "nos coloca diante do desafio de uma proposta de ecologia integral, que nos convida a uma conversão e exige reconhecer nossos próprios erros, pecados, vícios, negligências e omissões com as quais ofendemos a criação de Deus" (LS 218). Paulo Suess (2019) afirma que a reforma missionária da Igreja precisa acontecer a partir da Amazônia. Que uma "Igreja por sua natureza missionária” (AG 2) precisa ser aberta, sair de si, “caminhar junto com seu povo, ser sinal de transformação, optar pelos pobres, despojar-se das amarras que impedem uma ação ousada diante das exigências e desafios emergentes da realidade local”. Frisa ele que o Papa alerta que "na doação, a vida se fortalece e, se enfraquece, no comodismo e no isolamento [...]; a vida se alcança e amadurece na medida em que se a entrega, para dar vida aos outros" (EG 10).

É nesse sentido, coerente com a sua missão, que a lgreja se propôs trilhar o caminho que reconhece e promove as culturas dos povos amazônidas. Já não quer ceder a privilégios nem fazer alianças com aqueles que detêm o poder econômico ou político. Deseja estar livre para promover os direitos dos humildes. Descarta o clericalismo, para se colocar a serviço dos mais necessitados e contribui para esses serem agentes ativos na missão transformadora e libertadora da Igreja da Amazônia. Enfim, a Igreja anseia voltar à raiz da Missio Dei e da Igreja primitiva, que se encarna e se insere na realidade, toca, escuta e acolhe a sabedoria dos povos, em vista da ecologia integral. Quer ser uma presença libertadora e transformadora, abrindo novos caminhos para realização de sua vocação, por natureza, missionária.

\subsection{Nova forma de ser Igreja: em saída missionária}

O Papa Francisco, no encontro com os povos da Amazônia em Puerto Maldonado/Peru, disse que a Igreja na Região precisa ter "um rosto amazônico, um rosto indígena". Para isso, faz-se necessário uma Igreja “em saída" (EG 20-23), ousada e corajosa (EG 85,129), uma Igreja que reflete a própria presença de Cristo, que optou pelos que mais necessitavam, tendo presente os cenários desafiadores sempre novos. Segundo o Papa, precisamos da sabedoria e dos conhecimentos dos habitantes das terras amazônicas, "para podermos penetrar - sem destruir — o tesouro que encerra esta região". Considera "imprescindível fazer esforços 
para gerar espaços institucionais de respeito, reconhecimento e diálogo com os povos nativos, assumindo e resgatando a cultura, a linguagem, as tradições, os direitos e a espiritualidade que lhes são próprios" (PAPA FRANCISCO, Puerto Maldonado, 2018).

Para Paulo Suess (2019, p. 22), a "saída missionária" tem sentido geográfico — ir para as "periferias do mundo" e, também, sentido metafórico — deixar o "imobilismo". Implica rever cristalizações, que engessam expressões vivas da nossa fé. Segundo ele, o Sínodo Pan-Amazônico tem a "tarefa de reconfigurar a sinodalidade" para prática da missionariedade, do serviço, da escuta e da inclusão do povo local como sujeito da missão na Amazônia. Para tanto, é imprescindível "um diálogo intercultural" no qual os amazônidas sejam "os principais interlocutores, especialmente quando se avança com grandes projetos", que comprometem seus espaços (cf. LS 146). Frente a isso, a Igreja está ciente que os modelos utilizados para a pastoral estão ultrapassados e precisam ser renovados, com a participação do povo da Região. É o povo local o mais apto para falar de suas belezas, necessidades de preservação e recuperação da vida. Da mesma forma, é esse povo quem pode falar melhor de suas dores e perdas. Por isso, precisa ser o principal sujeito nessa missão de preservação, reparação e restituição.

Neste sentido, o Sínodo abre a possibilidade de audaciosas formas de presença e atuação "pastoral dos agentes locais, que atuam na região amazônica" de forma descentralizada, sinodal e decolonizada ${ }^{4}$. A Igreja precisa abrir mão de estruturas e modelos antigos e retrógrados, pois não se adequam mais à realidade atual (Instrumentum Laboris 35). A Igreja está ciente de que só é possível "compreender o mundo do outro, principalmente dos marginalizados", se acolhermos as "suas percepções, na concretude da vida" (CUNHA 2017, p. 25-26).

Destarte, a nova forma de presença da Igreja em "saída missionária", geográfica e metafórica, implica sair da zona de conforto para a "inclusão social dos pobres", o “diálogo social” em busca de justiça, paz e dignidade para todos. Por conseguinte, apresenta-se a exigência de buscar nova forma de presença baseada na responsabilidade e no compromisso com a ecologia integral (cf. EG 17,

\footnotetext{
${ }^{4}$ Segundo Walsh (2019, p. 14-15) decolonizar "é apontar e provocar um posicionamento - uma postura e atitude contínua - de transgredir, intervir, emergir e influenciar. O decolonial denota, então, um caminho de luta contínua no qual podemos identificar visualizar e incentivar 'lugares' de exterioridade e construções alternativas".
} 
288; LS 10). É assim que a Igreja profética, em saída missionária, mãe e samaritana, pode estar sempre em movimento ao encontro dos que foram empobrecidos, marginalizados e subalternizados por empreendimentos dos poderosos invasores das terras e predadores de suas riquezas. A Igreja como mãe precisa se preocupar, defender e cuidar de seus filhos e filhas mais necessitados com carinho especial. Como samaritana, precisa se aproximar, cheia de misericórdia, se curvar para ajudar, ao mesmo tempo em que se levanta para defendê-los e arregaça as mangas no trabalho de restauração. José Maria Vigil (2011, p. 37) afirma que a Igreja, "ao assumir o compromisso com os oprimidos e ser um com eles, testemunha publicamente o espírito profético da tradição cristã perante os poderes constituídos".

Com o Sínodo, a Igreja na Amazônia quer assumir uma presença ativa, que toca a realidade, na escuta das pessoas. Isso demonstra uma nova atitude, uma nova postura e um novo jeito de ser Igreja, encarnada na realidade dos pobres e necessitados. Assim, torna-se portadora de uma mensagem de libertação, buscando ser aquela que serve. Renuncia a ser uma "Igreja de visita" para ser uma "Igreja da presença". Sente que é preciso dar as mãos, formar correntes para fortalecer a pressão na luta contra toda exploração e devastação da Amazônia e a opressão de seus povos. Deseja, por meio de uma presença ativa, real, significante, participativa e encarnada na realidade e na vida do povo, fortalecer a voz dos povos locais e contribuir para que seus gritos sejam ouvidos.

Paulo Suess (2019, p. 24) acredita na "coerência e relevância” desse Sínodo, ao se propor superar "as promessas e afirmações normativas da Igreja", através de práticas concretas no seio da realidade amazônica. Só assim uma Igreja em saída missionária poderá marcar presença em todas as instâncias da Região, numa relação de diálogo, de modo que os "povos indígenas sejam os principais interlocutores", por se tratar de projetos em seu espaço vital. Para isso, urge uma nova configuração da instituição eclesial, "criando ministérios adequados para este período histórico", de modo que se possa ter realmente uma Igreja com rosto amazônico e indígena (Instrumentum Laboris 43).

Não obstante, o Sínodo se propôs, em primeiro lugar, a escutar a voz e o clamor da terra que geme e dos povos que gritam por socorro perante exploradores da Região, dar as mãos, formar correntes e partir para a ação. Isso exige mudanças de paradigmas pessoais, pastorais, estruturais e missionários. É condição para termos uma nova forma de presença inculturada e intercultural — 
"uma liturgia inculturada será também caixa de ressonância para as lutas e aspirações das comunidades e impulso transformador, em vista de uma 'terra sem males"' (cf. SC 37-40).

A Igreja em saída missionária para terras amazônicas quer assumir, com seriedade, a tarefa da inculturação da liturgia nas culturas dos povos locais, em especial dos indígenas, como um ato de reconhecimento e respeito à criatividade da criação divina, que se manifesta na diversidade das culturas, a fim de enriquecê-la (SC 65, 77, 81). Porquanto, é nas diferentes culturas que a Igreja precisa atuar e "exprimir sua genuína catolicidade" (cf. EG 116) - "é preciso ter coragem de encontrar os novos sinais, os novos símbolos, uma nova carne para a transmissão da Palavra, as diversas formas de beleza que se manifestam em diferentes âmbitos culturais" (EG 167).

A consciência missionária de uma Igreja sempre em saída, aberta e acolhedora, acena para uma nova forma de presença eclesial. Primeiro, trata-se da Igreja sair de si para se tornar próxima, fazendo-se presente, vendo e tocando, sentindo e escutando, discernindo como e quem deve atuar. Segundo, apresentando o Evangelho da maneira mais compreensível ao povo local. $\mathrm{Na}$ Amazônia, faz-se necessária uma atenção especial aos símbolos, buscando a melhor forma de introduzi-los na liturgia. Com isso, as celebrações podem se tornar mais alegres e festivas, celebradas nas línguas nativas, com suas danças, músicas, trajes, "em comunhão com a natureza e com a comunidade. [...], enfim, celebrações ligadas à luta e sofrimentos e alegria do povo". É preciso superar a rigidez, a exclusão e a insensibilidade pastoral, por uma corajosa decisão em preparar ministros locais para celebrar a Eucaristia, com a devida inculturação dos ritos nas culturas, "para assegurar os sacramentos que acompanhem e sustentam a vida cristã" (cf. Instrumentum Laboris 129). Apreciar as expressões populares de fé do povo, sua sabedoria e espiritualidade local, sem dúvida, é um grande passo para uma forma de presença descentralizada, decolonizada e aberta à interculturalidade e à sinodalidade.

A Igreja reconhece que as comunidades locais são lugares de aprendizagem da vida em comunidade, da partilha e da solidariedade. Também são lugar de aprendizagem sobre organização social, descentralização da autoridade e liderança rotativa, aquela que serve gratuitamente a todos. O Instrumentum Laboris número 128 destaca a necessidade de uma pastoral de presença permanente em todas as suas expressões e não somente de visitas pastorais. Do 
mesmo modo, o ministério, a liturgia, os sacramentos, a teologia e os serviços sociais precisam não apenas estar presentes, como partir da experiência espiritual dos povos locais. O Espírito de Deus sopra onde quer e derrama seus dons sobre todos/todas e sobre todas as culturas.

Neste sentido, para melhor responder às necessidades da Igreja da Amazônia, é preciso voltar às raízes da Igreja primitiva. São as comunidades eclesiais locais que têm melhor conhecimento de sua cultura, língua e tradição. Assim sendo, é urgente e necessário criar novos ministérios a homens e mulheres locais para atingir as áreas mais remotas da região amazônica. Por isso, além da ordenação de indígenas, é preciso promover o protagonismo dos leigos e o papel e liderança da mulher com seu carisma e talento.

Quanto à vida consagrada, esta está convidada a dispensar o tempo necessário para inserir-se no meio dos mais pobres e necessitados, sendo testemunha profética do amor, da escuta e do serviço. É basilar dedicar tempo para escutar o povo, estudar e aprender as línguas, conhecer a cultura, a fim de desenvolver um vínculo profundo com o povo. Logo, há a necessidade de uma formação intercultural e de uma espiritualidade a partir da cosmovisão amazônica (cf. Instrumentum Laboris 129). A concretude de uma Igreja em saída missionária implica uma nova forma de presença do ser cristão. Significa saber sair, saber chegar e saber estar transformando-se em um verdadeiro sinal da alegria e da libertação do Evangelho e do Reino, tornando-os presente no mundo.

\subsection{Uma missão em perspectiva decolonizadora}

O Cardeal C. Hummes (2018, p. 116) frisa que a missão da Igreja na Amazônia consiste "prioritariamente na proteção da população local" como um todo. A "proteção da população exige necessariamente a proteção do meio-ambiente, a natureza, a 'casa comum”", na certeza de que “proteger a Amazônia, é proteger o planeta e as gerações futuras". Assim, sem receio e temor, a Igreja precisa corajosamente abraçar a realidade amazônica, trilhando "novos caminhos" que levem à plena decolonização e transformação do rosto da Igreja. O Sínodo Especial para a Amazônia traz uma nova forma de presença da Igreja na região, promove uma Igreja missionária pobre e dos pobres, inculturada, misericordiosa, samaritana, de presença e convívio constante no meio do povo, com o protagonismo das lideranças locais (HUMMES, 2018, p. 116). 
A proposta de uma missão decolonizadora a partir dos povos da Amazônia é uma tarefa desafiadora, a ser corajosamente assumida pela Igreja. É um convite a olhar para a história desses povos, ver e tocar marcas visíveis da devastação de suas terras e de suas vidas. A reconhecer suas lutas pela sobrevivência e pelo direito negado de possuir o que já lhes pertence: terras, cultura, língua, costumes e tradições. Por isso, o Sínodo é um apelo para se aproximar e retomar o tema delicado de uma história negada, que faz doer feridas abertas por constantes invasões predatórias e destruidoras da vida e das terras da região amazônica. É um grande e corajoso salto para a abertura missionária em perspectiva decolonizadora. Segundo Paulo Suess (2019, p. 27), "a Igreja 'com rosto amazônico' vai procurar nas raízes dos povos aborígenes as soluções para seu futuro, articulando sua emancipação política com a identidade cultural”.

Segundo o Papa Francisco, "a mentalidade cega e destruidora que favorece o lucro está matando a Amazônia”. E, “diante dessa situação, a Igreja não pode permanecer indiferente, nem em silêncio, pois os efeitos repercutem a nível planetário" (AMAZÔNIA..., 2019). Sabemos que os predadores de hoje atuam com os mesmos objetivos e intenções dos colonizadores de ontem, a saber: explorar e expulsar, provocando a perda das culturas originais e destruindo a natureza. Eles calam e escravizam até exterminar os povos nativos. Tudo isso em nome de uma “civilização" dominante e dominadora. É diante dessa situação que a voz profética da Igreja precisa ressoar dos altos dos telhados, ao lado das vozes dos povos que gritam por vida, justiça e dignidade. Frisa o Papa, que "nunca os povos originários amazônicos estiveram tão ameaçados em seus territórios como agora, [...] por novos colonizadores [...] mascarados de progresso que não levam em conta os seus habitantes" (PAPA FRANCISCO, Puerto Maldonado, 2018).

Os povos indígenas sempre estiveram em uma luta constante, reivindicando seu território, seus direitos, dignidade e vida; sempre estiveram chorando a morte trazida pela devastação sem limites da natureza por parte dos invasores. Eles nunca desistiram da luta apesar de tantos desafios, sofrimentos e mortes. Segundo Cunha (2017, p. 19) o desafio de decolonizar "emerge da situação de empoderamento das minorias, privilegia a cultura nativa, não cede a privilégios nem a alianças" com os poderosos. Logo, uma missão em perspectiva decolonizadora precisa partir da base, da união dos povos originários. Precisa apoiar, dar voz e vez, resgatar, recuperar, estancar todo tipo de destruição e injustiças que atentem contra o povo local. Precisa convidar a uma missão 
encarnada na Amazônia, com seu povo, sua história e lutas por libertação. Trata-se de um processo de conversão e de reconciliação, que leva a um olhar diferente e a um compromisso concreto, de não somente parar com a exploração e depredação do bioma amazônico e de seus povos, como também a se engajar em sua restauração e cuidado.

Segundo Silva (2010), uma missão decolonizadora "é um tema que exige situar-se num lugar determinado e de lá abrir-se para o diálogo". Assim sendo, a Igreja é desafiada a dar passos largos e firmes e apostar em diferentes caminhos, em vista de uma missão comprometida, profética e libertadora, que assuma a tarefa "de decolonizar as mentes e devolver a liberdade à alma, ao espírito humano" (SILVA, 2010, p. 76). Trata-se de uma inovação missionária audaciosa, tal como colocam em relevo as Conferências de Santo Domingo (1992) e de Aparecida (2007), desafiando a Igreja à conversão pastoral e missionária. Uma transformação ad intra e ad extra da ação evangelizadora da Igreja. O Documento de Aparecida n. 75 reconhece que os povos indígenas, juntamente com outros grupos marginalizados, precisam assumir o protagonismo como sujeitos na sociedade e na política, para fortalecer a democracia participativa.

No Instrumentum Laboris, nota-se uma atitude da Igreja de profunda conversão em relação aos povos e às culturas autóctones, ao considerar esses grupos como sujeitos e protagonistas da evangelização. Teve-se a coragem de tomar posição em favor de uma missão em clave decolonizadora5, que por tanto tempo legitimou e ou se calou diante da exclusão dos povos originários. Assim, a missão na realidade amazônica não tem como não ser decolonial, ou seja, como não partir das pessoas que lá vivem e lutam contra um sistema colonial revestido de modernidade e de desenvolvimento civilizatório. Esse tipo de colonialidade moderna capitalista investe contra a Amazônia, a fim de explorar e, de maneira mais sofisticada, causar destruições muito maiores, mais rápidas e com maior vigor que no passado.

O camaronês Achille Mbembe (2014), ao abordar a questão dos povos que sofreram colonização, usa o conceito de "reparação", aludindo ao dever moral de

\footnotetext{
5 "O projeto colonial, além da conquista da terra, implicou o controle da subjetividade, da cultura, do conhecimento, dos povos masculino e feminino, e, em especial, da produção de conhecimento dos povos colonizados. Para impor uma cultura de dominadores e dominados" em que "o negro e o indígena desapareceram dentro do projeto colonizador", a missão seguiu essa linha de transposição de um cristianismo todo revestido da cultura europeia, matando as culturas autóctones (SILVA, 2010, p. 79).
} 
restituir, àqueles e àquelas que foram tratados como coisas ou são abstratos para história, a "parte da humanidade que lhes foi roubada". Trata-se da "reunião de partes que foram amputadas, para a reparação de laços que foram quebrados, condição para se atingir a humanidade" (MBEMBE, 2014, p. 304). Nesse sentido, para a Amazônia não basta preservação, mas é preciso reparação e restituição da vida agredida ou violada. Segundo ele, a humanidade precisa se comprometer com a preservação e a reconstituição das "reservas de vida", caso contrário, estará condenada à morte precoce (MBEMBE, 2014, p. 302). Adverte ele (2014, p. 303) que "existe apenas um mundo" e todos temos direito a ele, apesar das diferentes maneiras de habitá-lo. Daí a necessidade de respeitar e cuidar da nossa "casa comum" para que vivamos em paz, garantindo que as gerações futuras também vivam nele. Neste sentido, não se pode negar que a Amazônia é parte importante do planeta assim como sua preservação e recuperação, o que beneficiará todo o planeta. Sua destruição terá consequência ecológica mundial.

Ainda segundo o autor, nos tempos modernos, é preciso ter em mente "o irreversível processo de interação e entrelaçamento das culturas, povos e nações”. Isso não é um problema, ao contrário, enriquece sempre que na relação há interculturalidade e partilha de conhecimento, experiências, espiritualidade, reconhecimento da alteridade, uma relação de respeito, confiança, cuidado e amor. Todos os seres humanos têm em comum a vida, o "desejo de ser"; a "plenitude humana é algo que todos partilhamos" (MBEMBE, 2014, p. 304). Assim, cada vez mais, tudo e todos se tornam muito próximos e isso deveria propiciar maior partilha e reciprocidade. No entanto, a história e a presente realidade do mundo e da Amazônia mostram que muitos agem pautados pelo desejo de explorar e dominar e acabam por destruir. A Igreja corajosamente quer levar a cabo uma missão na Amazônia diferente do passado, quando, na era colonial, ela costumava se unir aos poderosos. Sua decisão, hoje, de se unir aos povos locais, para frear os invasores e predadores e, assim, buscar salvar a Amazônia é, sem dúvida alguma, um processo decolonizador de si mesmo e contribui para a decolonização dos povos, que continuam sob o julgo da colonialidade moderna.

Infelizmente, os invasores da era colonial não estão extintos, como também a mentalidade colonial continua invadindo e devastando, fantasiada de desenvolvimento e de modernidade, quando na realidade é expressão do domínio do utilitarismo economicista. A Igreja não quer fazer parte desse sistema colonizador, predador e destruidor, nem ficar calada, porque ela se importa com a 
vida. Por isso, toma iniciativas e atitudes proféticas, como a de escutar, anunciar e denunciar onde a vida está sendo ameaçada. Isso é fruto de um longo "processo de conversão ecológica e pastoral, para deixar-se interpelar seriamente pelas periferias geográficas e existenciais" (cf. Instrumentum Laboris 44; EG 20).

Infelizmente, os agravos e violências não são coisas do passado. Ainda hoje, com máscaras diferentes, continuam provocando danos colossais. A mentalidade capitalista e consumista da modernidade, que se sente no direito de dominar e explorar, acumular e descartar coisas e pessoas que vivem à margem e nas periferias existenciais continua crescendo. Hoje, um dos meios sofisticados e rápidos de colonizar se dá pelos meios de comunicação, que chegam a matar a língua e a cultura local e incutem na mente das pessoas ofertas enganosas. $\mathrm{Na}$ Amazônia, os povos indígenas querem comunicação em suas próprias línguas e a valorização de suas culturas, costumes e tradições, e não a morte delas. É o estrangeiro quem deve inserir-se na cultura e aprender a língua dos povos locais e não o contrário. Por isso, a Igreja na Amazônia quer apoiar e promover os povos originários e a população local, tendo uma "presença estável" em seu seio, conhecendo as "línguas autóctones", suas culturas, costumes, sua tradição religiosa e "experiência espiritual” (cf. Instrumentum Laboris 129).

Em resumo, uma missão em perspectiva decolonizadora na Amazônia significa reconhecer a soberania dos amazônidas, fortalecê-los em suas culturas, bem como restaurar e proteger suas terras. Implica pensar em uma missão inclusiva e plural, sensível à realidade local, aos seus conhecimentos e manifestações culturais. Trata-se de valorizar modos alternativos de pensar a vida na Igreja e no mundo, particularmente daqueles enraizados nas culturas indígenas e na realidade local. E para que seja realmente uma missão decolonizadora, é importante que esse processo missionário seja protagonizado pelos amazônidas, que sofrem diretamente as consequências de um modelo de desenvolvimento predatório da vida e das riquezas de seu rico bioma.

\section{Considerações finais}

Pastoral e teologicamente, o horizonte aberto pelo Concílio Vaticano II permitiu romper com o eclesiocentrismo dos períodos de cristandade e neocristandade, marcado por uma missão centrípeta, que consistia em sair para fora da Igreja, a fim de trazer adeptos para dentro dela. Na ótica da Evangelii 
Nuntiandi, que recolhe a contribuição dos processos pastorais e da reflexão teológica levada a cabo na América Latina, se passou a compreender a evangelização não mais como implantação da Igreja, mas como a encarnação do Evangelho, através de uma relação dialógica e horizontal, no encontro entre culturas, numa relação intercultural. A versão de cristianismo do missionário, sempre condicionada pela própria cultura, não é nem modelo e nem ponto de partida para a missão evangelizadora. Se o ponto de partida do processo de evangelização não for o outro e sua cultura, a missão continuará atrelada, consciente ou inconscientemente, a modelos colonizadores, numa dinâmica diametricamente oposta à do Evangelho. "Descolonizar as mentes" foi um forte apelo de Aparecida. Por sua vez, na proposta de uma "Igreja em saída", o Papa Francisco fala da urgência de ir para as periferias, mas com o cuidado de não "domesticar as fronteiras".

Para uma evangelização consequente com o contexto amazônico, as Igrejas Locais da Região precisam fazer de seu Sínodo um passo importante na configuração de Igrejas autóctones, expressão de uma eclesiologia pluriforme, conforme o modelo neotestamentário. É a hora de ousar, pois apesar da abertura do novo pontificado, juridicamente, continua a milenar centralização que impede responder com mais agilidade e propriedade aos desafios oriundos de um contexto muito particular. Fundado na legitimidade do exercício da sinodalidade eclesial entre as Igrejas Locais e a Igreja de Roma, os frutos do Sínodo para a Amazônia precisam ser expressão da autonomia necessária das Igrejas Locais para tomar decisões diante de certas demandas do contexto amazônico que não podem esperar.

\section{Referências}

ALLEGRETTI, M. Usar para valorizar. História, Revista da Biblioteca Nacional, ano 4, n. 44, Rio de Janeiro, p. 22-25, maio 2009.

AMAZÔNIA sofre com mentalidade cega e destruidora que favorece o lucro. Estadão, 06 jul. 2019. Disponível em: <https://noticias.uol.com.br/ultimas-noticias/agenciaestado/2019/07/06/amazonia-sofre-com-mentalidade-cega-e-destruidora-que-favorece-olucro-diz-papa.htm>. Acesso em: 13 ago. 2019.

BALDISSERI, L. Comenta o Documento Preparatório sobre a assembleia sinodal de 2019. Apresentado em 08 Jun 2018 na Sala de Imprensa da Santa Sé - a Amazônia no coração da 
Igreja. Disponível em: < https://www.vaticannews.va/pt/vaticano/news/2018-06/sinodobispos-amazonia.html>. Acesso em: 22 Jul2019.

BARBOSA DE ALMEIDA, M. W. Floresta que sangra. -História, Revista da Biblioteca Nacional, ano 4, n. 44, Rio de Janeiro, p. 18-21, maio 2009.

BERNO DE ALMEIDA, A. W. Mapeando vidas. História, Revista da Biblioteca Nacional, ano 4, n. 44, Rio de Janeiro, p. 28-31, maio 2009.

BOFF, L. Ecologia. Grito da Terra, grito dos pobres. Rocco: Rio de Janeiro, 1995.

BOFF, L. Ecologia, Mundialização, Espiritualidade. Ática: São Paulo, 1996.

BOFF, L. La dignidad de la tierra. Ecología, mundialización, espiritualidad. La emergencia de um nuevo paradigma. Trota: Madrid, 2000.

BOFF, L. Cuidar la tierra. Hacia una ética universal. Dabar: México, 2001.

CONSELHO EPISCOPAL LATINO-AMERICANO. Documento de Aparecida, Texto conclusivo da $V$ Conferência Geral do Episcopado Latino-Americano e Caribe. $5^{\text {a }}$ ed. São Paulo: Paulus, 2008.

CUNHA, C. Provocações Decoloniais à teologia cristã. São Paulo: Edições Terceira Via, 2017.

HUMMES, C. C. A proteção da Amazônia e de seus povos originários. CONCILIUM -Revista Internacional de Teologia, Petrópolis, n. 5, v. 378, p. 113-118, 2018.

MBEMBE, A. Crítica da razão negra. Lisboa: Antígona, 2014. (Título original, Critique de la raison nègre. Trad. Marta Lança. París: Éditions de La Découverte, 2013.

PAPA FRANCISCO. Carta Encíclica: Laudato Si': Sobre o cuidado da casa comum (2005). Disponível em:

<http://www.vatican.va/content/francesco/pt/encyclicals/documents/papa-

francesco_20150524_enciclica-laudato-si.html>. Acesso em: 22 jul. 2019.

PAPA FRANCISCO. Encontro com os povos da Amazônia, discurso do Santo Padre Puerto Maldonado - Coliseu Madre de Dios. 19 de janeiro de 2018.

PAPA FRANCISCO. Exortação apostólica "Evangelii Gaudium” - A alegria do Evangelho: sobre o anúncio do Evangelho no mundo atual. São Paulo: Paulus, 2013.

SCHMINK, M. A cidadania florestal. História, Revista da Biblioteca Nacional, ano 4, n. 44, Rio de Janeiro, maio, 2009.

SILVA, S. R. de L. Uma missão descolonizadora de nossas mentes em relação aos afrodescendentes. Ciberteologia - Revista de Teologia \& Cultura, ano VI, n. 28, p. 76-86, 2010.

SÍNODO DE LOS BISPOS ASAMBLEA ESPECIAL PARA LA REGIÓN PANAMAZÓNICA. Amazonía: nuevos caminos para la Iglesia y para una ecología integral. Instrumentum Laboris. Vaticano, 17 de junho de 2019. 
SPADARO, A. Entrevista exclusiva do Papa Francisco ao Pe. Antonio Apadaro, SJ. São Paulo: Paulus, 2013.

SUESS, P. A proposta do Papa Francisco para o sínodo Pan-Amazônico de 2019: sinodalidade, missão, ecologia integral. Perspectiva Teológica, Belo Horizonte v. 51, n. 1 p. 15-30, jan./abr. 2019.

VIGIL, J. M. (Org.). Por uma teologia planetária. São Paulo: Paulinas, 2011.

VIOLA, E. O regime internacional de mudanças climáticas e o Brasil. RBCS, Rio de Janeiro, v. 17, n. 50, p. 25-46, out. 2002. 